\title{
Analysis of clinical data and $T$ helper 1/T helper 2 responses in patients with different clinical forms of leprosy
}

\author{
Ricardo Wilson de Pinho Rodrigues ${ }^{[1],[2]}$, Afonso Bezerra Ribeiro ${ }^{[2]}$, \\ Gilcele de Campos Martin Berber ${ }^{[3]}$, LeeYun Sheng ${ }^{[4]}$ \\ and Amilcar Sabino Damazo ${ }^{[2],[5]}$
}

\begin{abstract}
[1]. Instituto de Ciências da Saúde, Universidade Federal do Mato Grosso, Sinop, MT, Brasil. [2]. Curso de Programa de Pós-Graduação em Ciências da Saúde, Faculdade de Medicina, Universidade Federal do Mato Grosso, Cuiabá, MT, Brasil. [3]. Faculdade de Sinop, Sinop, MT, Brasil. [4]. Instituto de Ciências Naturais e Humanas, Universidade Federal do Mato Grosso, Sinop, MT, Brasil. [5]. Departamento de Ciências Básicas em Saúde, Faculdade de Medicina, Universidade Federal do Mato Grosso, Cuiabá, MT, Brasil.
\end{abstract}

\begin{abstract}
Introduction: Currently, there are no laboratory tests or sensitive and specific molecular markers for the early diagnosis of leprosy. The aim of this study was to analyze the clinical characteristics of patients with leprosy and investigate their immunological profile, comparing this with the type of lesion and the presence or absence of a Bacillus Calmette-Guérin (BCG) vaccination scar. Methods: Statistical analyzes were performed by employing comparative tests (Pearson's chi-square) to evaluate the variables in different clinical forms, considering significance at the 5\% level. Results: The study identified a predominance of lepromatous leprosy (26.9\%) in patients aged between 34-53 years. Caucasians predominantly had borderline tuberculoid (BT) clinical forms (42\%); a predominance of males with borderline lepromatous $(19 \%)$ and lepromatous leprosy $(26.9 \%)$ forms was observed; and the presence of BCG vaccination scars $(27.5 \%)$ and lower limb nerves were more affected (38\%) predominantly in the BT clinical form. Significant differences were identified, which included hypochromic lesions predominantly in the BT clinical form (24\%); diffuse-type lesions predominantly in the tuberculoid (TT) clinical form (28\%); ill-defined lesion border dominance in lepromatous leprosy (LL) clinical forms (30\%); an irregular lesion limit predominantly in LL clinical forms (32\%); and a predominant Th1 immune response in the BT clinical form (41.7\%). Conclusions: The evaluation of the immunological profile in leprosy patients may contribute to the more detailed diagnosis and possibly better characterization of the prognosis for these individuals.
\end{abstract}

Keywords: Mycobacterium leprae. Epidemiology. Th1/Th2 response. Tuberculoid. Lepromatous.

\section{INTRODUCTION}

Leprosy has a high rate of infectivity and low pathogenicity; however, majority of the population do not develop the disease. This fact indicates that there is an association of genetic and environmental factors on susceptibility and cause of resistance ${ }^{1,2}$. The correct diagnosis of leprosy requires evolutionary clinical data of the disease, histopathological analysis and sputum smear microscopy, enabling determination of the form presented by the patient, such as: TT (tuberculoid), BT (borderline tuberculoid), BB (borderline borderline), BL (borderline lepromatous) and LL (lepromatous leprosy) ${ }^{3,4,5}$. This classification is necessary for the appropriate, specific therapeutic option to be delivered ${ }^{6,7}$.

Corresponding author: Prof. Amilcar Sabino Damazo.

e-mail: damazoas@pq.cnpq.br

Received 14 October 2016

Accepted 24 March 2017
There are major differences in the endemicity of leprosy between different regions of Brazil. Mato Grosso is the State with the highest prevalence of leprosy; in 2014, the rate was 10.19 cases/10,000 inhabitants, which exceeds the national rate of 1.27 cases $/ 10,000$ inhabitants $^{8}$. There is a need to intensify leprosy surveillance, with more effective diagnosis and treatment of the disease, with an emphasis on the regions with the highest rates of disease in the country 9

The immune response is of prime importance to disease susceptibility or resistance, fundamental to the defense of the organism against exposure to the bacillus, and is also associated with the development of the different clinical forms ${ }^{10}$. These forms range from tuberculoid, with a predominantly cellular immune response, to lepromatous leprosy dominated by a humoral response ${ }^{4,11}$. These responses are associated with specific mechanisms for the recognition of antigens, mediated by receptors present on the membranes of $\mathrm{T}$ and $\mathrm{B}$ lymphocytes ${ }^{12,13}$. The immune response can be categorized into cellular or type 1 and humoral or type 2 . The ability of lymphocytes with the cluster of differentiation $4(\mathrm{CD} 4+)$, also known as helper T lymphocytes 
(Th), to induce cellular or humoral responses is related to the types of cytokines secreted at the site of inflammation ${ }^{14,15,16}$. The predominance of a cellular or a humoral immune response to infection with the bacillus may influence the evolution of the disease ${ }^{17}$. TT patients have strong cellular immune response against $M$. leprae, which could limit the disease to a few well-defined skin and nerves lesions ${ }^{18}$. In patients with the LL type, there is no specific cellular immune response against $M$. leprae as bacterial proliferation occurs, with the presence of many lesions and extensive infiltration of the skin and nerves ${ }^{19}$. CD4 ${ }^{+} \mathrm{T}$ lymphocytes are more abundant in tuberculoid lesions, whereas $\mathrm{CD}^{+}$lymphocytes, which can represent a suppressor phenotype, predominate in lepromatous lesions ${ }^{20,21}$. In tuberculoid lesions, the distribution of lymphocytes is more ordered, with $\mathrm{CD}^{+} \mathrm{T}$ lymphocytes in the center of the lesions and $\mathrm{CD}^{+} \mathrm{T}$ lymphocytes with suppressive function ${ }^{22}$.

The aim of this study was to analyze the clinical characteristics of patients with leprosy and investigating their immunological profile, comparing this with the type of lesion and the presence or absence of a scar related to Bacillus Calmette-Guérin (BCG) vaccination.

\section{METHODS}

\section{Patients}

This was a cross-sectional study of patients examined in the Diagnosis and Treatment Leprosy Service section, located at the Hospital Universitário Júlio Müller (HUJM), the Teaching Hospital of Universidade Federal de Mato Grosso (UFMT), Cuiabá, Mato Grosso State, Brazil, between November 2013 and September 2014. Seventy patients were categorized based on the clinical forms, according to the established criteria ${ }^{23}$.

A standard questionnaire was used to collect information regarding the age, race, sex, lesion characteristics (color, type, border), region of the affected nerves, and presence or absence of a BCG vaccination scar. General physical and dermatological/ neurological examinations were performed on all patients by the medical doctor responsible for the service. We assessed the overall condition of the patient's health and the lesion characteristics such as color (erythematous, hyperchromic, hypochromic), type (diffuse, plaque or nodular), border (well defined, ill defined), limit (irregular or regular) and an evaluation of the affected area of nerves (upper limbs and lower limbs) and protective sensation of hands and feet, through an esthesiometer with the use of Semmes-Weinstein $(\mathrm{SW})^{24}$.

Patients with comorbities, immunosuppressive diseases, renal failure and pregnant patients were excluded from our study.

\section{Ethical considerations}

This study meets the Resolutions No. 196/96 and No. 347 of 13 January 2005, of the National Health Council and was approved by the HUJM Ethics Committee, with protocol number 733/CEP-HUJM /09. All patients were asked to voluntarily participate in the research project. The informed consent form (ICF) was read to each participant, and the interview process was done only after the signing of the ICF.

\section{Biopsy for histopathology}

Asepsis and local anesthesia with $2 \%$ lidocaine without a vasoconstrictor were performed, which showed that a lesion has the clinical characteristic of leprosy. Further, a biopsy was performed using a $4 \mathrm{~mm}$ punch of the lesion. After the biopsy was collected, the tissue specimen was immersed in $10 \%$ buffered formalin and transported to the histopathology laboratory of HUJM/UFMT, to examine the lesion. Samples were washed in the same buffer, dehydrated in solutions with increasing ethanol concentration, clarified in xylene and embedded in paraffin. The paraffin blocks containing the tissue specimens were cut into sections $(5 \mu \mathrm{m})$ for histology, using the HIRAX M60 microtome (Carl Zeiss; Germany). Subsequently, the sections were placed on slides, and after the process of deparaffinization and rehydration, they were stained with hematoxylin-eosin for histopathological analysis, which allowed identification of epithelioid and vacuolated histiocytes, multinucleated giant cells, lymphocytes and plasma cells, and regions of epithelial damage. In addition, another section was cut in order to perform the Fite-Faraco staining, which was used for the identification of AFB (acid-fast bacilli).

\section{Immunofluorescence for the identification of Th1 and Th2 cells at the site of inflammation}

The identification of Th1 and Th2 cells was performed in histological sections $(5 \mu \mathrm{m})$ of skin biopsies from patients by immunofluorescence staining. Sections for immunohistochemistry were prepared on slides with biological adhesive (BIOBOND; British Biocell International, Cardiff, UK) and subsequently incubated with the following reagents at room temperature, as described previously ${ }^{25}:$ a) incubated in a water bath at $100^{\circ} \mathrm{C}$ in $0.21 \%$ sodium citrate solution for 30 min; b) blocked with $3 \%$ hydrogen peroxide in $70 \%$ methanol for $1 \mathrm{~h}$; c) permeabilized by incubation with $0.4 \%$ Tween 20 in phosphate buffered saline (PBS) for $15 \mathrm{~min}$; d) blocked with $5 \%$ bovine serum albumin (BSA), diluted in PBS for 1h; e) incubated with the primary antibodies: rabbit anti-CD4 (ABCAM, USA) (1:100 in 1\% BSA), mouse anti-CC-chemikine receptor 5 (CCR5) (ABCAM, USA) (1:100 in 1\% BSA), for the detection of membrane markers for Th1, and anti-CCR4 mouse (ABCAM, USA) (1:100 in 1\% BSA), for the detection of membrane marker for Th2. Slides were incubated with the antibody solution for $18 \mathrm{~h}$ at $4^{\circ} \mathrm{C}$ in a moist chamber.

For visualization of the antigen-antibody labeling region, the following secondary antibodies were used: donkey anti-rabbit IgG conjugated to ALEXAFLUOR 488 fluorochrome (Invitrogen, USA, 1:50 in 1\% BSA) and goat anti-mouse IgG conjugated to ALEXAFLUOR 546 fluorochrome (Invitrogen, USA, 1:50 in $1 \% \mathrm{BSA}$ ). Slides were incubated for $1 \mathrm{~h}$ at room temperature and in a dark chamber. Furthermore, nuclear DAPI (4',6-diamidino2-phenylindole) was used for examining nuclear morphology. Excess fluorescent reagent was washed with PBS and the slides were mounted using Citifluor mounting media (DAKO, USA).

\section{Statistical analysis}

Tables were created to describe patient and lesion characteristics including the age, race, sex, lesion (color, type, border), region of the affected nerves, presence of a BCG 
vaccination scar, and Th1/Th2 immunoreactivity, associated with varying clinical forms of leprosy. Pearson's chi-square test was performed to verify the association of each variable to the clinical form ${ }^{26,27,28}$. Data were analyzed using Excel 2010 software and SPSS (version 20), considering a 5\% level of significance.

\section{RESULTS}

Leprosy clinical form was not statistically associated with patient age, race or sex (p-value $=0.74,0.07$ and 0.10 , respectively) (Table 1). With respect to patient age, 26 patients were aged between 34-53 years, with a predominance of the BT $(n=7$; $26.9 \%)$ and LL ( $\mathrm{n}=7 ; 26.92 \%)$ clinical forms. Of the reported cases, 24 were aged between 14-3 years, with a predominance of TT $(\mathrm{n}=6 ; 25.0 \%)$ and BB $(\mathrm{n}=6 ; 25.0 \%)$ clinical forms. Further, 19 patients were older than 54 years, with a predominance of the TT $(n=4 ; 21.0 \%)$ and BL ( $=6 ; 31.6 \%)$ clinical forms. Twenty-six patients were Caucasian with a predominance of the TT $(n=6$; $2 \%)$ and $\mathrm{BT}(\mathrm{n}=11 ; 42.3 \%)$ clinical forms; 24 were Mulatto, with a predominance of the BL $(\mathrm{n}=6 ; 25.0 \%)$ and $\mathrm{LL}(\mathrm{n}=6$; $25.00 \%)$ forms; 20 were Black, with a predominance of the BB $(\mathrm{n}=5 ; 25.0 \%)$ and $\mathrm{LL}(\mathrm{n}=6 ; 30.0 \%)$ forms. With respect to sex, 42 were males, predominantly with $\mathrm{BL}(\mathrm{n}=11 ; 26.2 \%)$ and $\mathrm{LL}$ $(\mathrm{n}=11 ; 26.2 \%)$. The TT $(\mathrm{n}=6 ; 21.4 \%)$ and BT $(\mathrm{n}=10 ; 35.7 \%)$ clinical forms were predominantly found in the female patients.

We found significant associations to the varying clinical forms in relation to the color of the lesion $(\mathrm{P}=0.001)$, type of injury $(\mathrm{P}=0.027)$, lesion border characteristics $(\mathrm{P}=0.001)$ and limits (irregular versus regular) of the lesions $(\mathrm{P}=0.001)$ (Table 2). Thirty-three of the cases were hypochromic, with a predominance of TT $(n=12 ; 36.4 \%)$ and BT $(n=8$; $24.2 \%) 23$ were erythematous, with a predominance of
$\mathrm{BL}(\mathrm{n}=7 ; 30.4 \%)$ and $\mathrm{LL}(\mathrm{n}=7 ; 30.4 \%) ; 14$ were hyperchromic, with a predominance of the BT $(n=5 ; 35.7 \%)$ and $\mathrm{BB}(\mathrm{n}=3$; $21.4 \%$ ). As for the type of lesion, 50 cases were diffuse, with a predominance of the TT form $(\mathrm{n}=13 ; 26.0 \%)$ and BT $(\mathrm{n}=11$; $22.0 \%) ; 12$ were plaques with a predominance of the BT $(n=4$; $33.33 \%)$ and $\mathrm{BB}(\mathrm{n}=4 ; 33.33 \%)$ forms; 8 were nodular with a predominance of the BV $(n=3 ; 37.5 \%)$ and LL $(n=5 ; 62.5 \%)$ forms. As for the lesion border characteristics, 43 of the cases were ill-defined, with a predominance of the $\mathrm{BL}(\mathrm{n}=13 ; 30.2 \%)$ and LL ( $\mathrm{n}=13 ; 30.2 \%)$ clinical forms; 27 were well-defined, with a predominance of the TT $(n=12 ; 44.0 \%)$ and BT $(n=7$; $25.9 \%$ ) forms. With regard to the limits of the lesion, 37 cases were irregular, predominantly BL $(\mathrm{n}=10 ; 27.0 \%)$ and $\mathrm{LL}(\mathrm{n}=12$; $32.4 \%) ; 33$ of the cases were regular, with a predominance of the TT $(n=12 ; 36.4)$ and BT $(n=9 ; 27.3 \%)$ forms. In the analysis of the region of the affected nerves, no significant association was observed $(P=0.639)$.

Statistical associations were not found between the clinical form and the presence of a BCG vaccination scar $(P=0.359)$ (Table 3). Forty patients had a BCG scar, with a predominance of the BT $(n=8 ; 26.7 \%)$ and BL $(n=10 ; 25.0 \%)$ clinical forms; 30 cases had no scar, with a predominance of the TT $(n=8 ; 26.7 \%)$ and $\mathrm{LL}(\mathrm{n}=7 ; 23.3 \%)$ forms.

Immunoreactivity, in terms of $\mathrm{Th} 1 / \mathrm{Th} 2$ responses, was observed by immunostaining with the cell markers CD4/CCR5 and CD4/CCR4 (Figure 1). The staining profile was associated with the differing clinical forms $(P=0.001) ; 36$ cases were Th1, with a predominance of the TT $(\mathrm{n}=11 ; 30.6 \%)$ and $\mathrm{BT}(\mathrm{n}=15$; $41.7 \%$ ) forms; 34 were Th2, with a predominance of the BL $(\mathrm{n}=12 ; 35,3 \%)$ and $\mathrm{LL}(\mathrm{n}=13 ; 38,2 \%)$ forms (Table 4$)$.

There was a significant association $(P=0.001)$ between the clinical form of leprosy, the presence of a BCG vaccination

TABLE 1

Association of age, race, and sex of patients with the varying clinical forms of leprosy.

\begin{tabular}{|c|c|c|c|c|c|c|}
\hline & \multicolumn{5}{|c|}{ Clinical form } & \multirow[b]{2}{*}{ p-value* } \\
\hline & $\begin{array}{c}\text { TT } \\
\text { n (\%) } \\
\end{array}$ & $\begin{array}{c}\text { BT } \\
\text { n (\%) } \\
\end{array}$ & $\begin{array}{c}\text { BB } \\
\text { n (\%) } \\
\end{array}$ & $\begin{array}{c}\text { BL } \\
\text { n (\%) } \\
\end{array}$ & $\begin{array}{c}\text { LL } \\
\text { n (\%) } \\
\end{array}$ & \\
\hline \multicolumn{7}{|l|}{$\overline{\text { Age }}$} \\
\hline $34-53$ & $3(11.4)$ & $7(26.9)$ & $4(15.4)$ & $5(19.2)$ & $7(26.9)$ & \\
\hline Caucasians & $6(23.1)$ & $11(42.3)$ & $3(11.5)$ & $3(11.5)$ & $3(11.5)$ & \\
\hline Blacks & $2(10.0)$ & $2(10.0)$ & $5(25.0)$ & $6(30.0)$ & $5(25.0)$ & \\
\hline mulatto & $5(20.8)$ & $2(8.3)$ & $5(20.8)$ & $6(25.0)$ & $6(25.0)$ & 0.07 \\
\hline \multicolumn{7}{|l|}{$\overline{\operatorname{Sex}}$} \\
\hline
\end{tabular}

TT: Tuberculoid leprosy; BT: Borderline tuberculoid; BB: Borderline borderline; BL: Borderline lepromatous; LL: Lepromatous leprosy. "chi-square test. Leprosy patients examined in Júlio Muller Teaching Hospital ambulatory in Cuiaba, Mato Grosso. 


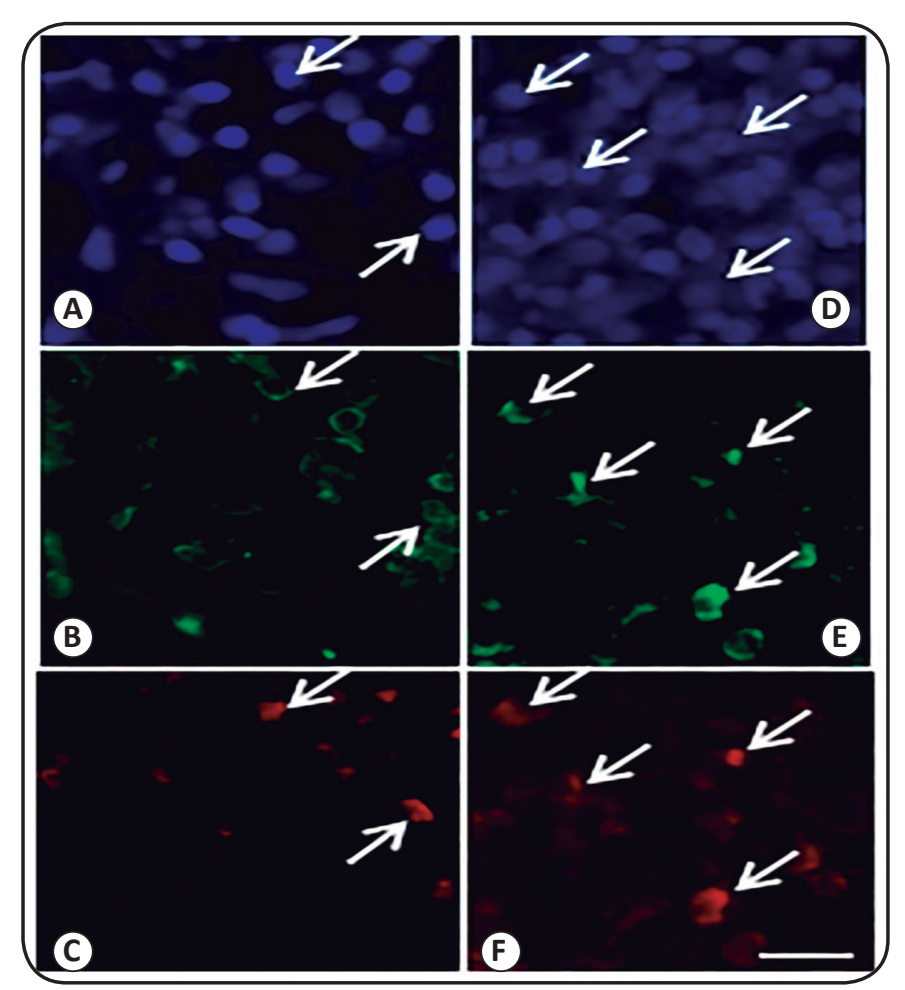

FIGURE 1 - Immunofluorescence analysis for CCR5 and CCR4. Figure 1 A, B and C: Tuberculoid leprosy patients with lymphocytes immunostained for DAPI (Panel A), CD4 (Panel B), and CCR5 (Panel C). Figure 1 D, E and $\mathrm{F}$ : Lepromatous leprosy patients with lymphocytes immunostained for DAPI (Panel D), CD4 (Panel E) and CCR4 (Panel F). Bar $=50 \mu \mathrm{m}$. CCR: CC-Chemokine receptor; DAPI: 4',6-diamidino-2-phenylindole; CD4: cluster of differentiation 4 scar, and Th1/Th2 immunoreactivity (Table 5). This analysis showed that in 19 of the cases that had a BCG scar and Th1 immunoreactivity, there was a predominance of the TT clinical form $(\mathrm{n}=5 ; 26.3 \%)$, and 17 of the cases with no BCG scar and the presence of Th1 immune response had a prevalence of the TT $(n=6 ; 35.3 \%)$ form. Twenty-one cases also had no BCG scar and a Th2 immune response, with a predominance of the $\mathrm{BL}(\mathrm{n}=9 ; 42.7 \%)$ form. Thirteen of the cases had no BCG scar and the presence of a Th2 immune response, with a prevalence of LL $(n=6 ; 46.0 \%)$.

\section{DIscussion}

To date, there is no laboratory test or sensitive and specific molecular markers for the effective and early diagnosis of leprosy ${ }^{29}$, with a diagnosis mainly based on clinical examination. Thus, this study examined the influence of Th1/Th2 immune response on the clinical and histopathological variables, with the objective of identifying possible patterns that may aid in the prognosis of the different clinical forms of leprosy. Various researchers have reported techniques for leprosy diagnosis that may increase our understanding of the epidemiology and transmission of the disease, with the ultimate goal of developing new intervention strategies to prevent leprosy ${ }^{30}$.

Although this study focused on the patients treated at the Júlio Müller Teaching Hospital in the city of Cuiabá, many of the patients were from the neighboring municipals, and also use this service. Of the entire patient cohort, the age groups 14-33 and 34-53 years each represented one-third of the total patient population. This suggests that leprosy affects large number of

TABLE 2

Association of color of the lesion, type of lesion, lesion border and limits, and region of nerves affected for patients with varying clinical forms of leprosy.

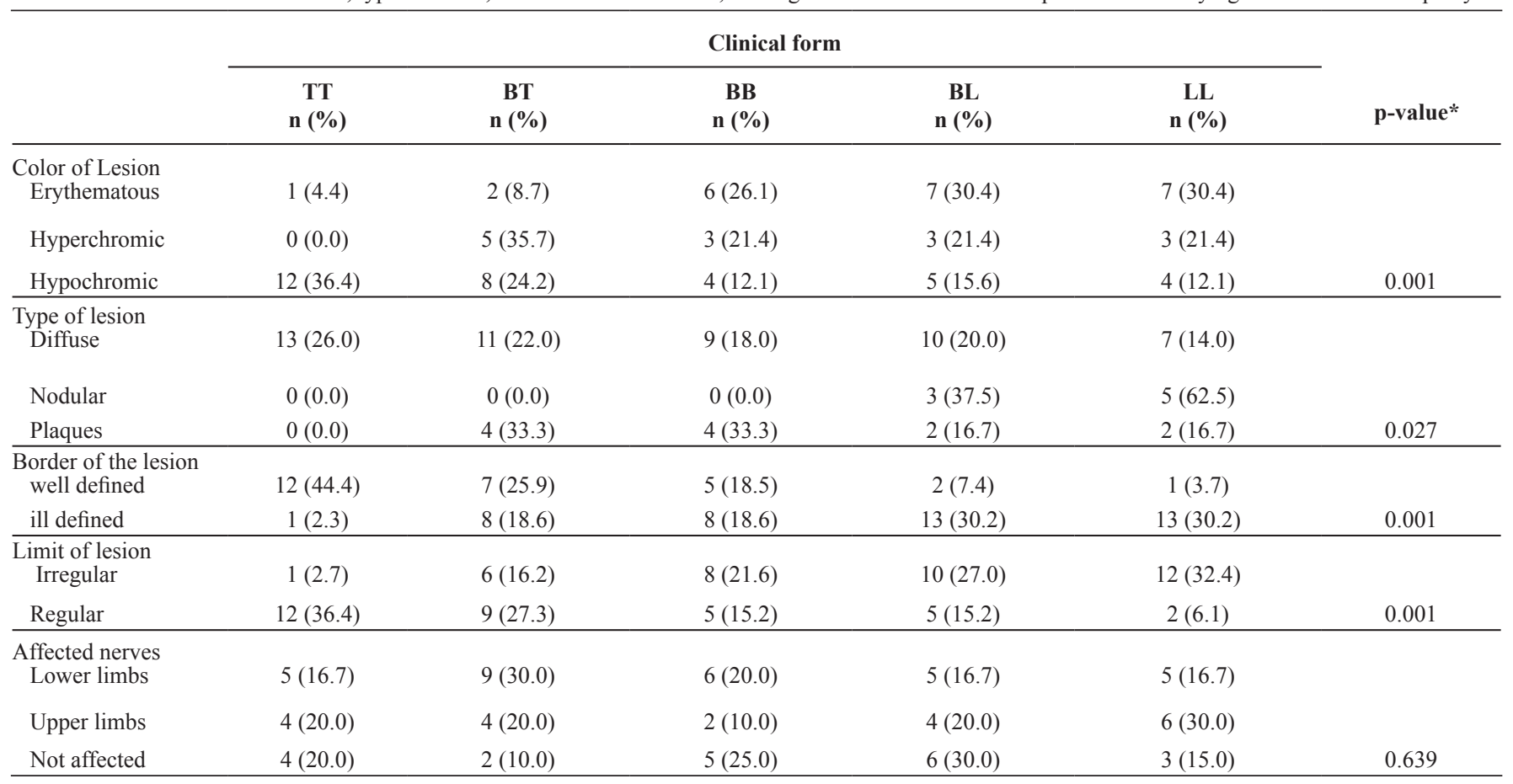

TT: Tuberculoid leprosy; BT: Borderline tuberculoid; BB: Borderline borderline; BL: Borderline lepromatous; LL: Lepromatous leprosy. *chi-square test. Leprosy patients examined in Júlio Muller Teaching Hospital ambulatory in Cuiaba, Mato Grosso. 
TABLE 3

Association of the presence of a BCG vaccination scar with varying clinical forms of leprosy.

\begin{tabular}{lccccc}
\hline & \multicolumn{5}{c}{ Clinical form } \\
\cline { 2 - 5 } & $\begin{array}{c}\text { TT } \\
\mathbf{n}(\%)\end{array}$ & $\begin{array}{c}\mathbf{B}(\%) \\
\mathbf{n}(\%)\end{array}$ & $\begin{array}{c}\text { BB } \\
\mathbf{n}(\%)\end{array}$ & $\begin{array}{c}\text { BL } \\
\mathbf{n}(\%)\end{array}$ & $\begin{array}{c}\text { LL } \\
\mathbf{n}(\%)\end{array}$ \\
\hline BCG & $8(26.7)$ & $4(13.3)$ & $6(20.0)$ & $5(16.7)$ & $7(23.3)$ \\
No & $5(12.5)$ & $11(7.5)$ & $7(17.5)$ & $10(25.0)$ & $7(17.5)$ \\
Yes & & & & 0.36 \\
\hline
\end{tabular}

BCG: Bacillus Calmette-Guírin; TT: Tuberculoid leprosy; BT: Borderline tuberculoid; BB: Borderline borderline; BL: Borderline lepromatous; LL: Lepromatous leprosy. *chi-square test. Leprosy patients examined in Júlio Muller Hospital Teaching ambulatory in Cuiaba, Mato Grosso.

TABLE 4

Association of the immunoreactivity in patients with varying clinical forms of leprosy.

\begin{tabular}{lccccc}
\hline & \multicolumn{5}{c}{ Clinical form } \\
\cline { 2 - 5 } & $\begin{array}{c}\text { TT } \\
\mathbf{n}(\mathbf{\%})\end{array}$ & $\begin{array}{c}\text { TB } \\
\mathbf{n}(\mathbf{\%})\end{array}$ & $\begin{array}{c}\text { BB } \\
\mathbf{n}(\mathbf{\%})\end{array}$ & $\begin{array}{c}\text { BL } \\
\mathbf{n}(\mathbf{\%})\end{array}$ & $\begin{array}{c}\text { LL } \\
\mathbf{n}(\mathbf{\%})\end{array}$ \\
\hline $\begin{array}{l}\text { Immunoreactivity } \\
\text { Th1 }\end{array}$ & $11(30.6)$ & $15(41.7)$ & $6(16.7)$ & $3(8.3)$ & $1(2.8)$ \\
Th2 & $2(5.9)$ & $0(0.0)$ & $7(20.6)$ & $12(35.3)$ & $13(38.2)$ \\
\hline
\end{tabular}

TT: Tuberculoid leprosy; BT: Borderline tuberculoid; BB: Borderline borderline; BL: Borderline lepromatous; LL: Lepromatous leprosy. *chi-square test. Leprosy patients examined at Júlio Muller Teaching Hospital ambulatory in Cuiaba, Mato Grosso.

TABLE 5

Association of BCG scar and immunoreactivity with varying clinical forms of leprosy.

\begin{tabular}{|c|c|c|c|c|c|c|c|}
\hline & & \multicolumn{5}{|c|}{ Clinical form } & p-value* \\
\hline \multirow[t]{2}{*}{ Th1 } & No & $6(35.3)$ & $4(23.5)$ & $4(23.5)$ & $2(11.8)$ & $1(5.9)$ & \\
\hline & Yes & $5(26.0)$ & $11(57.9)$ & $2(10.5)$ & $1(5.3)$ & $0(0.0)$ & \\
\hline Th2 & Yes & $0(0.0)$ & $0(0.0)$ & $5(23.8)$ & $9(42.7)$ & $7(33.3)$ & 0.001 \\
\hline
\end{tabular}

TT: Tuberculoid leprosy; BT: Borderline tuberculoid; BB: Borderline borderline; BL: Borderline lepromatous; LL: Lepromatous leprosy. *chi-square test. Leprosy patients examined in Júlio Muller Teaching Hospital ambulatory in Cuiaba, Mato Grosso.

individuals in the economically productive population, which causes high economic impacts due to their having to abstaining from work, caused by the development of permanent and physically disabling lesions ${ }^{31,32}$. Importantly, as these patients are not able to work, they have the right to seek sickness benefits and even disability retirement ${ }^{33}$. Associated with this, the most common clinical forms of leprosy in these patients are the BB, $\mathrm{BL}$, and LL forms, which have higher transmission capability and cause greater incapacitation ${ }^{34}$.

Regarding the ethnicity of patients, in our study, Caucasians were the predominant race, which differs from previous findings in the literature ${ }^{32,35,36}$ where Mulatos were the most prevalent affected population. It should be noted that many patients who are from different regions of the state and who are users of the HUJM in Cuiaba are predominantly Caucasians. The population of Mato Grosso is composed of $50.0 \%$ mixed race, $38.9 \%$ Caucasians and 9.8\% Blacks (IBGE, 2010) ${ }^{37}$. Magalhães ${ }^{38}$ considers that the migration process in Mato Grosso territory contributed to the spread and evolution of leprosy in the 1970s and 1980s, with large flows of people of Caucasian origin into the state. Few studies have reported the influence of ethnic variation as a factor of exposure to the bacillus.

Men were more affected in this study, and were associated with the BL and LL clinical forms (26\% each). These data are consistent with the findings in the literature ${ }^{39,40}$. According to Moreira et al. ${ }^{41}$ and Costa $^{1}$, men have greater risk for infection 
due to lifestyle factors. The higher incidence of physical disabilities in men may be related to less concern with selfimage, particularly in relation to the body and aesthetics; thus, men are less likely to access health services and this may contribute to late diagnosis and subsequently predispose the patient to become a propagator of the disease $\mathrm{e}^{42,43,44,45}$.

The dermato-histopathological characteristics of skin lesions found in our study are consistent with findings in the literature ${ }^{45,46,47,48}$. Assessment of the patients by dermatologic and histopathological data are fundamental to arrive at a more accurate diagnosis ${ }^{49,50}$.

Regarding the region of the affected nerves, in this study BT and BB forms were more frequent in the lower limbs compared with other clinical forms. The involvement of the peripheral nerves is present in all clinical forms of leprosy, and in tuberculoid forms, the nerve damage is usually earlier, while in lepromatous leprosy it appears later ${ }^{48,51}$. This variable is an important epidemiological indicator responsible for causing irreversible consequences, resulting in deformities and disabilities ${ }^{52,53}$. Early diagnosis of neural integrity and the degree of disability is key to determining follow-up strategies, in order to guide appropriate treatment, prevent the advancement of neural disability and contribute to the physical rehabilitation ${ }^{54,55,56}$.

Finally, the association of clinical forms with the immunoreactivity in terms of Th1 and Th2 responses associated with the type of leprosy patient was established. The literature shows that the CCR5 is a good cell marker for Th1 cells, as is CCR4 for Th2 cells $^{57}$. It is important to note that, in this study, we evaluated the skin lymphocytes, while in most studies, determination of phenotype of circulating leukocyte populations in the blood is assessed. In some studies that have compared the immunoreactivity of cells from the blood and the skin, the existence of dissimilar responses has been reported ${ }^{58,59}$. This demonstrates that, at the inflammatory site where bacteria are concentrated, the immune response may vary according to what is classically reported in the literature ${ }^{10}$.

In this study, the majority of patients showed Th1 immunoreactivity, with the BT clinical form present at the highest prevalence $(41 \%)$, while the remainder of the patients had Th2 characteristics, with a high prevalence of LL clinical forms $(38 \%)$. These data corroborate findings from other studies that have shown similar results ${ }^{58,59,60,61}$. However, other cell components may interfere with local immune responses and lymphocyte differentiation, such as the interaction with antigenic cells, like the Langerhans cells ${ }^{62}$ extracellular matrix components such as collagen fibers, fibronectin, and laminin ${ }^{63}$, and other factors such as hormones ${ }^{64}$. Thus, any changes in Th1 and Th2 response should be considered with caution. In addition, some studies have reported the tendency for variation in the immune response, especially in patients with borderline clinical profiles ${ }^{58}$.

The Th1/Th2 responses may have inconsistencies. Some patients may have different profile, including the presence of regulatory $\mathrm{T}$ cells or Th17 cells along with a classic Th1 or Th2 profile $54,58,65,66,67$. This differential response could lead to vulnerability to infection with the bacteria, or a change in the clinical profile of patients from the tuberculoid pole to lepromatous ${ }^{59}$. Future studies may indicate the presence of each cell type as a way to understand these changes in the immune profile of patients, and may thus enable further improvements in the prognosis of these patients.

Finally, the presence of a BCG vaccination scar in leprosy patients was assessed. Most of the patients had a vaccination scar, these being predominantly BT and BL clinical types. Several studies have shown that the BCG vaccine protects against leprosy, being one of the priority interventions established by the World Health Organization (WHO) to control the disease $\mathrm{e}^{50}$. Conversely, some studies have suggested varied protection by the BCG vaccine and this may be related to genetic factors ${ }^{68,69}$., In this study most patients with leprosy who had a BCG vaccination scar and a Th1 immune response were tuberculoid while most patients without a BCG scar and with a Th2 response were lepromatous. Some studies demonstrate that $\mathrm{BCG}$ vaccination makes the individual most likely to develop a profile of M1 macrophages, inducing them to produce pro-inflammatory cytokines such as IL- 1 and TNF- $\alpha$, thereby developing a greater resistance to the bacteria ${ }^{70}$.

In conclusion, immunological evaluation of patients with leprosy can contribute to the more detailed diagnosis and possibly better characterization of prognosis in these individuals. Further, public health policies should encouraged BCG vaccination for individuals without vaccine scar, in order to provide greater protection against this disease.

\section{Financial Support}

This study was supported by the Research Support Foundation of Mato Grosso (Fundação de Amparo a Pesquisa de Mato Grosso), Brazil, Grant no. 841967/2009 (PRONEX/FAPEMAT/CNPq) and Grant no. 754477/2011 (/FAPEMAT No. 009/2011). ASD was supported by the Brazilian National Council for Scientific and Technological Development (Conselho Nacional de Desenvolvimento Científico e Tecnológico; Grant no. 311986/2014-5).

\section{Conflict of Interest}

The authors declare that there is no conflict of interest.

\section{REFERENCES}

1. Costa RD. Estudo do perfil de citocinas inflamatórias, moléculas anti-inflamatórias e BDNF em pacientes com hanseníase. Dissertação de Mestrado em Clínica Médica e Biomedicina. Belo Horizonte: Santa Casa de Misericórdia de Belo Horizonte; 2008. 147 p.

2. Alter A, Grant A, Abel L, Alcais A, Schurr E. Leprosy as a genetic disease. Mamm Genome. 2011;22(1-2):19-31.

3. Foss NT. Aspectos imunológicos da hanseníase. Medicina, Ribeirão Preto. 1997;30:335-9.

4. Mendonça VA, Costa RD, Melo GEBA, Antunes CM, Teixeira AL. Imunologia da hanseníase. An Bras Dermatol. 2008;83(4):343-50.

5. Jopling WH, McDougall AC. Manual de Hanseníase. $4^{\mathrm{a}}$ edição. São Paulo: Atheneu, 1991. 183 p.

6. Nunes JM, Oliveira EN, Vieira NFC. Ter Hanseníase: percepções de pessoas em tratamento. Rev RENE. 2008;9(4):99-106. 
7. Orsini M, de Freitas MRG, Antonioli RS, Mello MP, Reis JPB, Reis CHM, et al. Estudos clínicos, imunopatológicos e eletrofisiológicos dos nervos periféricos na hanseníase. Rev Neurocienc. 2008;16(3):220-30.

8. Ministério da Saúde. Secretaria de Gestão do Trabalho e da Educação na Saúde. Mobilização reforça combate à hanseníase em Mato Grosso. Cuiabá: Universidade Aberta do SUS (UNA-SUS). 2015. Disponível em: http://unasus.gov.br/. Acesso em 20 abril de 2016.

9. World Healthy Organization (WHO). Global leprosy situation, 2012. Wkly Epidemiol Rec. 2012;87(34):317-28.

10. Goulart IMB, Penna GO, Cunha G. Imunopatologia da Hanseníase: a complexidade dos mecanismos da resposta imune do hospedeiro ao Mycobacterium leprae. Rev Soc Bras Med Trop. 2002;35(4): 365-75.

11. Araújo MG. Hanseníase no Brasil. Rev Soc Bras Med Trop. 2003;36(3):373-82.

12. Charo IF, Ransohoff RM. The roles of chemokines and chemokine receptors in inflammation. N Engl J Med. 2006;354(6):610-21.

13. Scapini P, Lapinet-Vera JA, Gasperini S, Calzetti F, Bazzoni F, Cassatella MA. The neutrophil as a cellular source of chemokines. Immunol Rev. 2000;177:195-203.

14. Lew W, Chang S, Tada Y, Nakmura K, Tamaki K. Serum monocyte chemoattractant protein-1 is elevated in lepromatous leprosy patients with high bacterial indices. Int J Lepr Other Mycobact Dis. 2002;70(2):129-31.

15. Hasan Z, Jamil B, Zaidi I, Zafar S, Khan AA, Hussain R. Elevated serum CCL2 concomitant with a reduced Mycobacterium-induced response leads to disease dissemination in leprosy. Scand J Immunol 2006;63(3):241-7.

16. Mendonça VA, Malaquias LC, Brito-Melo GE, Castelo-Branco A, Antunes CM, Ribeiro AL, et al. Short report: differentiation of patients with leprosy from non-infected individuals by the chemokine eotaxin/CCL11. Am J Trop Med Hyg. 2007:77(3):547-50.

17. Moraes MO, Cardoso CC, Vanderborght PR, Pacheco AG. Genetic of host response in leprosy. Lepr Rev. 2006;77(3):189-202.

18. Britton WJ. Leprosy. In: Cohen J, Powerly WG, editors. Infectious diseases. 2nd edition. London: Mosby; 2004. p. 1507-13.

19. Britton WJ, Lockwood DN. Leprosy. Lancet. 2004;363(9416): 1209-19.

20. Van Voorhis WC, Kaplan G, Sarno EN, Horwitz MA, Steinman RM, Levis WR, et al. The cutaneous infiltrates of leprosy: cellular characteristics and the predominant T-cell phenotypes. N Engl J Med. 1982;307(26):1593-7.

21. Narayanan RB, Bhutani LK, Sharma AK, Nath I. T cell subsets in leprosy lesions: in situ characterization using monoclonal antibodies. Clin Exp Immunol. 1983;51(3):421-9.

22. Hastings RC, Gillis TP, Krahenbuhl JL, Franzblau SG. Leprosy. Clin Microbiol Rev. 1988;1(3):330-48.

23. Ridely DS, Jopling WH. Classification of leprosy according to immunity: a five group system. Int J Lepr Other Mycobact Dis. 1966;34(3):255-73.

24. Lehman LF, Orsini MB, Nicholl AR. The development and adaptation of the Semmes Weinstein monofilaments in Brazil. J Hand Ther. 1993;6(4):290-7.

25. Damazo AS, Yona S, Flower RJ, Perretti M, Oliani SM. Spatial and temporal profiles for anti-inflammatory gene expression in leukocytes during a resolving model of peritonitis. J Immunol. 2006;176(7):4410-8.
26. Pozzebon M, Freitas HMR. Modelagem de casos: uma nova abordagem em análise qualitativa de dados? In: Anais do Encontro Anual da Associação Nacional de Pós-Graduação e Pesquisa em Administração. Foz do Iguaçu: ANPAD; 1998. p. 1-37.

27. Duarte T. A possibilidade da investigação a 3: reflexões sobre triangulação (metodológica). CIES - Centro de Investigação e Estudos de Sociologia. CIES e-Working Paper. 2009;60:1-24.

28. Braga LPV. Introdução à Mineração de Dados. $2^{\mathrm{a}}$ edição. Rio de Janeiro: E-papers Serviços Editoriais; 2005. 212 p.

29. Stefani MMA. Desafios na era pós genômica para o desenvolvimento de testes laboratoriais para o diagnóstico da hanseníase. Rev Soc Bras Med Trop. 2008;41(Suppl 2):89-94.

30. Pinheiro RO, Salles JS, Sarno EN, Sampaio EP. Mycobacterium leprae-host cell interactions and genetic determinants in leprosy: an overview. Future Microbiol. 2011;6(2):217-30.

31. Lustosa AA, Nogueira LT, Pedrosa JIS, Teles JBM, Campelo V. The impact of leprosy on health-related quality of life. Rev Soc Bras Med Trop. 2011;44(5):621-6.

32. Miranzi SSC, Pereira LHM, Nunes AA. Perfil epidemiológico da hanseníase em um município brasileiro, no período de 2000 a 2006. Rev Soc Bras Med Trop. 2010;43(1):62-7.

33. Ministério da Saúde. Secretaria de Vigilância em Saúde. Departamento de Vigilância Epidemiológica. Hanseníase e direitos humanos: direitos e deveres dos usuários do SUS (Série F. Comunicação e Educação em Saúde). Brasília: Ministério da Saúde; 2008. p. 72.

34. Flach DMAM, Andrade M, Valle CLP, Pimentel MIF, Mello KT. Análise da série histórica do período de 2001 a 2009 dos casos de hanseníase em menores de15 anos, no estado do RJ. Hansen Int. 2010;35(1):13 20 .

35. Lana FCF, Lanza MF, Melendez VG, Branco CA, Teixeira S, Malaquias LCC. Distribuição da hanseníase segundo o sexo no município de Governador Valadares, Minas Gerais, Brasil. Hansen Int. 2003;28(2):131-7.

36. Ferreira SMB, Ignotti E, Gamba MA. Fatores associados à recidiva em hanseníase em Mato Grosso, Centro-oeste de Brasil. Rev Saúde Pública 2011;45(4):756-64.

37. Instituto Brasileiro de Geografia e Estatística (IBGE). Censo Demográfico 2010. Brasília: IBGE, 2011. Disponível em: http:// www.ibge.gov.br/home/estatistica/populacao/censo2010/. (acessado em 20 de abril de 2016).

38. Magalhaes MCC, dos Santos ES, de Queiroz ML, de Lima ML, Borges RCM, Souza MS, et al. Migração e hanseníase em Mato Grosso. Rev Bras Epidemiol. 2011;14(3):386-97.

39. Souza CS. Hanseníase: formas clínicas e diagnóstico diferencial. Simpósio Hanseníase. Medicina, Ribeirão Preto. 1997;30(3):325-34.

40. Lana FCF, Amaral EP, Lanza FM, Lima PL, Carvalho ACN, Diniz LG. Hanseníase em menores de 15 anos no Vale do Jequitinhonha, Minas Gerais, Brasil. Rev Bras Enferm. 2007;60(6):696-700.

41. Moreira FL, Nascimento AC, Martins ELB, Moreira HL, Lyon AC, Lyon S, et al. Hanseníase em Alfenas: aspectos epidemiológicos e clínicos na região sul do estado de Minas Gerais. Cad Saude Colet 2009;17(1):131-43.

42. Hinrichsen SL, Pinheiro MRS, Jucá MB, Rolim H, Danda GJN, Danda DMR. Epidemiologic aspects of leprosy in the city of Recife, Pernambuco state, 2002 An Bras Dermatol. 2004;79(4):413-21.

43. Opromolla PA, Dalben I, Cardim M. Análise da distribuição espacial da hanseníase no Estado de São Paulo, 1991-2002. Rev Bras Epidemiol. 2005;8(4):356-64. 
44. Lana FCF, AmaralEP, Lanza FM, Saldanha ANSL. Desenvolvimento de incapacidades físicas decorrentes da hanseníase no Vale do Jequitinhonha, MG. Rev Latino-Am Enferm. 2008;16(6):993-7.

45. Ministério da Saúde. Secretaria de Vigilância em Saúde. Guia de Vigilância Epidemiológica. $6^{a}$ edição. Brasília: Ministério da Saúde; 2005. 806 p.

46. Coura JR. Síntese das Doenças Infecciosas e Parasitárias. $1^{\mathrm{a}}$ edição. Rio de Janeiro: Guanabara Koogan; 2008. 322 p.

47. Rotta O. Guia de Dermatologia: Clínica, Cirúrgica e Cosmiátrica. Barueri: Manole; 2008. $725 \mathrm{p}$

48. Lockwood DNJ, Suneetha L, Sagili KD, Chaduvula MV, Mohammed I, Van Brakel W, et al. Cytokine and protein markers of leprosy reactions in skin and nerves: baseline results for the North Indian INFIR cohort. PLoS Negl Trop Dis. 2011;5(12):e1327.

49. Barbieri CLA, Marques HHS. Hanseníase em crianças e adolescentes revisão bibliográfica e situação atual no Brasil. Pediatria 2009;31(4):281-90.

50. Lima LS, Jadão FRS, Fonseca RNM, Silva Junior GF, Barros Neto RC. Caracterização clínica- epidemiológica dos pacientes diagnosticados com hanseníase no município de Caxias, MA. Rev Bras Clin Med 2009;7:74-83.

51. Garbino JA, Marques Junior W, Barreto JA, Heise CO, Rodrigues MMJ, Antunes SL, et al. Primary Neural Leprosy: Systematic Review. Arq Neuro-Psiquiatr 2013;71(6):397-404.

52. Ministério da Saúde. Secretaria de Vigilância em Saúde. Manual de prevenção de incapacidades. $3^{a}$ edição. Brasília: Ministério da Saúde; 2008. 135 p.

53. Ministério da Saúde. Secretaria de Vigilância em Saúde. Portaria $\mathrm{n}^{\circ}$ 3.125, de 07 de outubro de 2010. Aprova as Diretrizes para Vigilância, Atenção e Controle da Hanseníase. Diário Oficial da União. 2010 (15/10/ 2010); Sessão 1:p. 55.

54. Alves ED, Ferreira TL, Ferreira IN, organizadores. Hanseníase: avanços e desafios. Brasília: NESPROM/UnB; 2014. 492 p.

55. Baialardi KS. O estigma da hanseníase: relato de experiência em grupo com pessoas portadoras. Hansen Int. 2007;32(1):27-36.

56. Raposo PM, Raposo AVC, Sanchez-González MA, Medeiros JLA, Nemes MIB. Avaliação de incapacidades em pessoas vivendo com hanseníase: análise do grau de incapacidade em Campina Grande. Cad Saude Colet 2009;17(1):221-3.

57. Andrew DP, Ruffing N, Kim CH, Miao W, Heath H, Li Y, et al. $\mathrm{C}-\mathrm{C}$ chemokine receptor 4 expression defines a major subset of circulating nonintestinal memory $\mathrm{T}$ cells of both Th1 and Th2 potential. J Immunol. 2001;166(1):103-11.
58. Howe RC, Wondimu A, Demissee A, Frommel D. Functional heterogeneity among CD4+ T-cell clones from blood and skin lesions of leprosy patients. Identification of T-cell clones distinct from Th0, Th1 and Th2. Immunology. 1995;84(4):585-94.

59. Saini C, Ramesh V, Nath I. CD4+ Th17 cells discriminate clinical types and constitute a third subset of non Th1, non Th2 T cells in human leprosy. PLoS Negl Trop Dis. 2013;7(7):e2338.

60. Berrington WR, Kunwar CB, Neupane K, van den Eeden SJF, Vary Junior JC, Peterson GJ, et al. Differential dermal expression of CCL17 and CCL18 in tuberculoid and lepromatous leprosy. PLoS Neg1 Trop Dis. 2014;8(11)e3263.

61. Venturini J, Soares CT, Belone AF, Barreto JA, Ura S, Lauris JR, et al. In vitro and skin lesion cytokine profile in Brazilian patients with borderline tuberculoid and borderline lepromatous leprosy. Lepr Rev. 2011;82(1):25-35.

62. Steinmann RM. The dendritic cell system and its role in immunogenicity. Annu Rev Immunol. 1991;9:271-96.

63. Matusyana T, Yamada A, Kay J, Yamada KM, Akiyama SK, Scholossman SF, et al. Activation of CD4 cells by fibronectin and anti-CD3 antibody. A synergistic effect mediated by the VLA-5 fibronectin complex. J Exp Med. 1989;170(4):1133-48.

64. Daynes RA, Araneo BA, Dowell TA, Huang K, Dudley D. Regulation of murine lymphokine production in vivo. III. The lymphoid tissue microenvironment exerts regulatory influences over T helper cell functions. J Exp Med 1990;171(4):979-96.

65. Fink S, Finiasz MR, Valdez R, de la Barrera S, Sasiain MC. Evaluacion de la produccion de citoquinas en enfermos de lepra. Medicina (B Aires). 1996;56(6):705-8.

66. Nath I, Vemuri N, Reddi AL, Jain S, Brooks P, Colston MJ, et al. The effect of antigen presenting cells on the cytokine profiles of stable and reaction all lepromatous leprosy patients. Immunol Lett. 2000;75(1):69-76.

67. Zhu J, Yamane H, Paul WE. Differentiation of effector CD4 T cell populations. Annu Rev Immunol. 2010;28(1):445-89.

68. Merle CS, Cunha SS, Rodrigues LC. BCG vaccination and leprosy protection: review of current evidence and status of BCG in leprosy control. Expert Rev Vaccines. 2010;9(2):209-22.

69. Setia MS, Steinmaus C, Ho CS, Rutherford GW. The role of BCG in prevention of leprosy: a meta-analysis. Lancet Infect Dis 2006;6(3):162-9.

70. Fallows D, Peixoto B, Kaplan G, Manca C. Mycobacterium leprae alters classical activation of human monocytes in vitro. J Inflamm. 2016;13(1):8. 